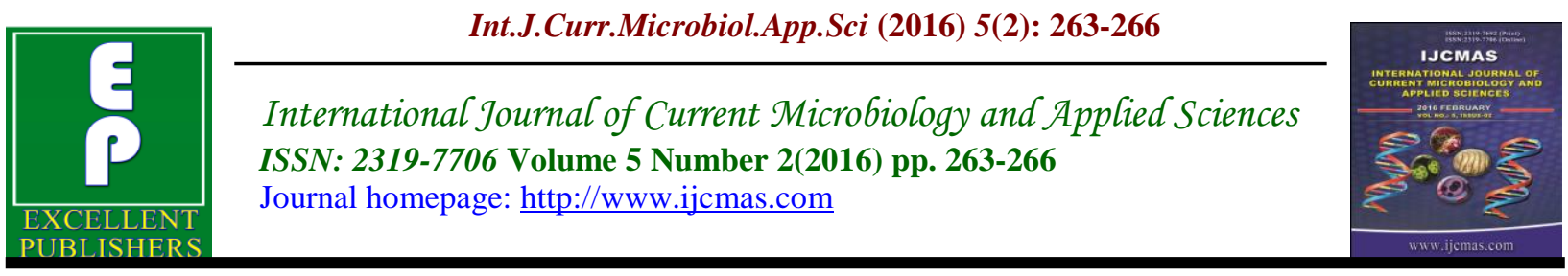

Case Study

doi: http://dx.doi.org/10.20546/ijcmas.2016.502.029

\title{
Aggressive Central Giant Cell Granuloma Mimicking Peripheral Giant Cell Granuloma - A Rare Case Report and Review of Literature
}

\author{
Ahtesham Ahmad*, Nilofar Ahtesham, Ashish S. Satpute and Gopal. L. Nagargoje \\ Department of Oral and Maxillofacial Surgery MIDSR Dental College Latur, Maharashtra, India \\ *Corresponding author
}

\begin{tabular}{|c|c|}
\hline & A B S T R A C T \\
\hline Keywords & \multirow{4}{*}{$\begin{array}{l}\text { Central giant cell granuloma is a benign lesion that usually occurs within the } \\
\text { jaw bones. Giant cell lesions are classified as aggressive and non-aggressive } \\
\text { lesions, based on the clinical and radiographic criteria. Non-aggressive } \\
\text { lesions in the jaw can be treated successfully by simple curettage with an } \\
\text { expected low recurrence rate. Aggressive lesions have recurrence rates as } \\
\text { high as } 70 \% \text { after enucleation or curettage. Pharmacologic therapy with } \\
\text { intralesional corticosteroids or calcitonin has been used to treat these } \\
\text { lesions, based on the assumption that the tumours are inflammatory or the } \\
\text { osteoclast is the primary cell of origin respectively. These treatments have } \\
\text { produced variable results. Here we report a case of aggressive Central giant } \\
\text { cell granuloma which was successfully treated by complete excision and } \\
\text { curettage with a one year follow up. }\end{array}$} \\
\hline $\begin{array}{l}\text { Curettage, } \\
\text { Giant cell } \\
\text { granuloma, } \\
\text { Recurrance }\end{array}$ & \\
\hline Article Info & \\
\hline $\begin{array}{l}\text { Accepted: } \\
\text { 15 January } 2016 \\
\text { Available Online: } \\
\text { 10, February } 2016\end{array}$ & \\
\hline
\end{tabular}

\section{Introduction}

Central giant cell granuloma is defined by the World Health Organization as an intraosseous lesion consisting of cellular fibrous tissue that contains multiple foci of hemorrhage, aggregations of multinucleated giant cells and occasionally trabaculae of woven bone. ${ }^{1}$ Before the early 1950 s, giant cell lesions of the jaws were generally diagnosed as giant cell tumours, and these lesions were widely considered to be similar to those that occurred in the extragnathic skeleton. ${ }^{2}$ In 1953 Jaffe proposed the term giant cell granuloma to distinguish these lesions from the giant cell tumors that are usually found in the epiphyseal regions of long bones.
It is widely appreciated, however that giant cell lesions of the jaws demonstrate variable clinical and histopathological behavior. Although most lesions are slow growing, circumscribed processes that respond well to simple curettage, a smaller number demonstrate aggressive clinical behavior that is characterized by pain, root resorption, cortical bone destruction, and tendency to recur after treatment. Because the clinical behavior of many of these lesions is inconsistent with a repairative reaction, the designation giant cell granuloma or the more non-committal term, giant cell lesion are most widely used today. ${ }^{3}$ 


\section{Case Report}

A 22year old male patient reported to the department of oral and maxillofacial surgery MIDSR, Dental college Latur with the chief complaint of a growth in the right lower back region of the jaw for the past 15 days. Patient gave history that he had a similar type of growth in the same region six months back, for which he had consulted a local dentist, who did extraction of the tooth and excision of the lesion. Patient was apparently normal post operatively but for the past 15 days he noticed similar type of growth in the same region, which was sudden in onset and had no other symptoms associated with the growth. No relevant past medical, family, and personal history was noted.

The general physical and extra oral examination was unremarkable. His intra oral examination revealed a solitary, sessile growth present in relation to mandibular right $1^{\text {st }}$ molar extending antero-posteriorly from mandibular right $1^{\text {st }}$ molar to mandibular right $3^{\text {rd }}$ molar and buccolingually from buccal vestibule to lingual vestibule approximately measuring about $1.5-3 \mathrm{~cm}$ in size, roughly oval in shape, reddish in colour,surface showed some lobulations, adjacent mucosa was normal(fig1).

On palpation, the growth was non-tender, did not bleed, was not associated with any discharge, firm in consistency and was movable. Based on history and clinical findings a provisional diagnosis of peripheral giant cell granuloma was made.

The orthopentomogram revealed mixed radiolucent and radiopaque areas extending from distal of mandibular right $2^{\text {nd }}$ premolar to mesial root of mandibular right $3^{\text {rd }}$ molar. It was irregular in shape, the lower and mesiolateral border was well corticated and the upper part of the cortical plates was destructed in the region of mandibular right $2^{\text {nd }}$ molar there is a dense radiolucent area measuring about $2-1 \mathrm{~cm}$ in size, and the inferior alveolar canal was pushed downwards(fig2).Based on radiographic features a diagnosis of central giant cell granuloma was made.

Patient was subjected to other investigative procedures to rule out hyperparathyroidism, like serum calcium, phosphate and parathormone levels which were in normal range. Incisional biopsy of the lesion was done and send for histopathological examination, which was suggestive of aggressive central giant cell granuloma (fig3).

After this the lesion was completely excised and thorough curettage of the area was done under general anesthesia (fig4). Follow up of one year was done and during this period no recurrence of the lesion was noticed (fig5).

\section{Discussion}

The central giant cell granuloma is a benign process that usually occurs within the jaw bones. The etiology of this lesion is unknown although various theories propose that it may be a reactive lesion or a repairative response to an intrabony hemorrhage or inflammation. Other investigators believe that central giant cell granuloma is a neoplastic lesion related to giant cell neoplasm of long bones. Regardless this lesion remains an area of controversy among the pathologists, ever since Jaffe first used the term giant cell repairative granuloma to differentiate it from the giant cell tumours. ${ }^{4,5,6 .}$

The central giant cell granuloma is a relatively common lesion, mostly found in the children and young adults, with $75 \%$ of 
the lesions occurring in the patients under 30 years of age. It affects females more frequently than males in a ratio of $2: 1$. It occurs almost exclusively in mandible and maxilla although cases involving other bones of facial skeleton, as well as small bones of hands have been reported. The mandible is more involved than maxilla and the lesion most frequently occurs anterior to molar teeth, with occasional extension across midline. The lesion produces a firm, painless, expansion of the involved area and the cortical plates are thinned but usually not perforated.

Figure.1 Pre Operative Photograph; Figure.2 Pre Operative Radiograph; Figure.3 Intra Operative Photograph; Figure.4 Excised Tissue Mass; Figure.5 Post Operative Radiograph After One Year Follow Up

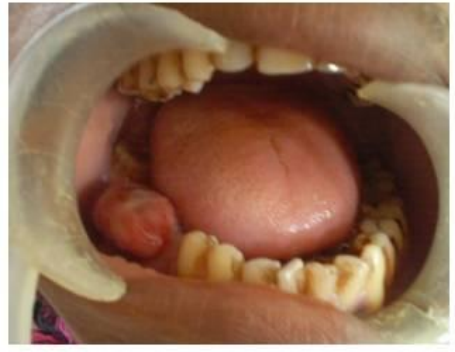

fig1

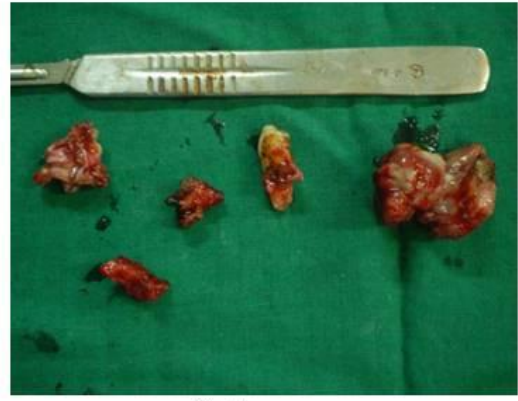

fig4

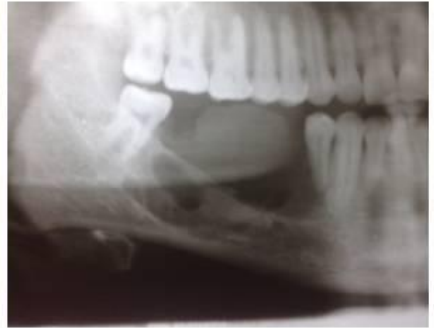

fig2

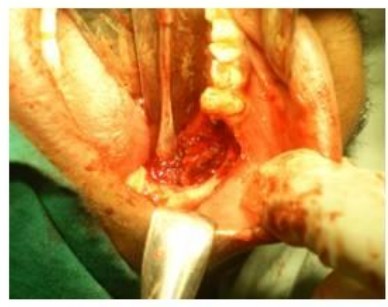

fig3

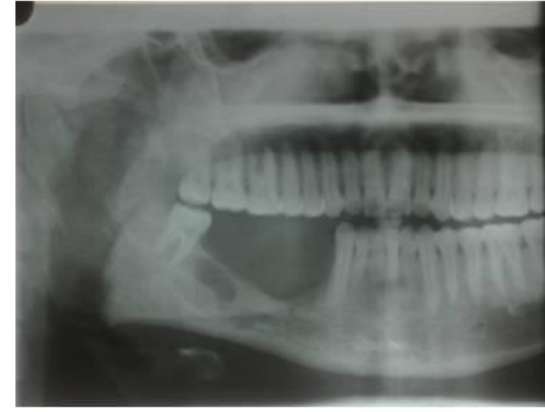

fig5
Central giant cell granuloms may be differentiated based on their clinical behavior into aggressive and non-aggressive lesions. The radiographic features initially consist of unilocular and as the lesion advances/enlarges, a multilocular radiolucensy with well defined borders that may displace or resorb the tooth roots.

The treatment of choice for central giant cell granuloma is surgical excision, with aggressive curettage and removal of peripheral bony margins, which results in a good prognosis and low recurrence rate. However several alternative treatment $\mathrm{s}$ have been suggested in the literature, including corticosteroid injections, calcitonin, and IFN-alpha.

In several studies the results of surgical therapy have been evaluated and recurrence rates ranging from $1-49 \%$ have been reported. 
The role of radiotherapy is controversial and should be reserved for special situations, that is inability to obtain adequate surgical margins due to the size of the lesion and with held in most cases due to its possible oncogenic potential.

\section{Conclusion}

Aggressive central giant cell granuloma occurring as peripheral one is a very rare case and the treatment of aggressive central giant cell granuloma with curettage has shown a high recurrence rate within a span of six months, but in our case even after one year followup, no recurrence of the lesion was noticed. So with conventional therapy when performed appropriately can be the treatment of choice even in cases of aggressive lesions.

\section{References}

1.Kafte.I,Ardekian.L,Taicher.s,Littner.MM, Buchner:A.Radiologic features of central giant cell granuloma of the jaws. Oral Surg Oral Med Oral
Pathol 1996;81:720-726.

2.Kramer IRH,Pindborg JJ,Shear.M:Histological typing of odontogenic tumours. $2^{\text {nd }}$ ed, Berlin: Springer-Verlag, 1991:31.

3.Whitaker.BS, Waldron.A : Central giant cell lesions of the jaws:a clinical,radiographic, and histopathologic study:Oral Surg Oral Med Oral Pathol 1993;75:199-208.

4.MiLoro.M, Quinn.DP.Synchronous central giant cell lesions of the jaws-:report of a case and review of literature. $\mathbf{J}$ Oral Maxillofac Surg.53:13501355,1995 .

5.Copetta. P,Salvati. M, Bernadi. C, etal: Giant cell repairative granuloma of the skull base mimicking an intracranial tumour:case report and review of literature. Surg Neurol 33:52.,1990.

6.Fesluk. H,Senders.C, Dublin.A: case report 562:Giant cell repairative granuloma of the temporal bone.Skeletal Radiol 18:599,1989.

\section{How to cite this article:}

Ahtesham Ahmad, Nilofar Ahtesham, Ashish S. Satpute and Gopal. L. Nagargoje. 2016. Aggressive Central Giant Cell Granuloma Mimicking Peripheral Giant Cell Granuloma - A Rare Case Report and Review of Literature. Int.J.Curr.Microbiol.App.Sci.5(2): 263-266. doi: http://dx.doi.org/10.20546/ijcmas.2016.502.029 